\title{
The One Who Knows: \\ On the Archetype of an Old Woman on the Basis of the Paratheatrical Activities of Ewa Benesz
}

\author{
Katarzyna Kułakowska \\ Correspondence: Katarzyna Kułakowska, Institute of Polish Culture, University of Warsaw, Warsaw, Poland
}

Received: August 31, 2016

Accepted: September 12, 2016

Available online: September 27, 2016

doi:10.11114/ijsss.v4i10.1849

URL: http://dx.doi.org/10.11114/ijsss.v4i10.1849

\begin{abstract}
This paper portrays Ewa Benesz, a great individuality moving within a borderland between theatre and para-theatre, literature and the art of telling stories. In her activities, she refers not only to the melody and rhythms originating from various cultures but also to traditional, everyday practices guaranteeing the generations durability, such as baking bread, producing wine or pressing olive.

In this ethnography I do not only describe my experience of being a participant of her original para-theatre workshops - In the act of creating - at her artistic residence turned into a hermitage in Sardinia, but I also interpret her artistic biography as a figuration of the One Who Knows, La Que Sabe according to the South American mythology, the archetypical woman "as old as time" who preserves the female tradition like a chronicler of the female practices using a special kind of language - the language of theatre, and possessing a special kind of imagination - the "anthropologic imagination"; and finally, having an experience which is the experience of a laborious and endurable creation of the theatrical trend of counterculture in Poland.
\end{abstract}

Keywords: Ewa Benesz, paratheatre, counter-culture, the one who knows, the anthropology of experience, women's studies, autoethnography

\section{Introduction}

"I am not an actress; I sometimes happen to be an actress", Ewa Benesz states, sitting on a sturdy trunk of an old tree which is standing in front of her Sardinian house, and which has a huge crown, densely woven of thick leaves, dark green all-year-long and almost velour in their texture. (Note 1). The 7-day paratheatrical workshop which she organises three times a year for a group of several dozen people coming from all parts of the world, among whom I also had a pleasure to be, has just been completed. "I am not a story-teller; I sometimes happen to be a story-teller. I am not an educationalist; I sometimes happen to be an educationalist", she declares. She is undoubtedly a great individuality associated with Polish counter-culture theatre, moving within a borderland between theatre and paratheatre, literature and the art of telling stories, who in 2013 celebrated her $70^{\text {th }}$ anniversary, coinciding with the $50^{\text {th }}$ anniversary of her artistic activity.

In this ethnography, I describe Ewa Benesz's experience of being an actress associated with Polish counter-culture theatre, interpreted by her in the form of biographical narrative and theatrical activities she conducted. I interpret her artistic biography as a figure of the One Who Knows, La Que Sabe according to the South American mythology, the archetypical woman "as old as time" who is a guardian of the mystery of a cyclical nature of life. The article aims at restoring the memory of the woman artist who has not been regarded as crucial or even have been omitted in prior synthetic and historical takes on theatre.

\subsection{The Unpopulated Territory of Feminine Counter-culture Theatre: Context and Significance of the Research}

This ethnography should be perceived as a part of my broader study on reinterpreting the history of Polish counter-culture theatre by dismantling its male-oriented perspective. The role and experiences of women in the Polish counter-culture theatre is a subject which still waits for its monograph. I reduce the term counter-culture to the specific moment in the history of culture encompassing youth protest movements which rose in America and almost all European countries at the end of 1960s (Roszak 1969). Counter-culture appeared in Poland with delay - its roots date back to 1970s and its heyday - to that decade's first half.

Surprisingly, in the presence of so many undertaken research works and practices of re-reading the history of Polish 
theatre, the issue of female participation in the counter-culture theatre has never been addressed by Polish scholars. Personage of Ewa Benesz, one of the greatest individuality associated with Polish counter-culture theatre, is also brushed by scholars aside (Note 2).

The most important and thematically comprehensive research project that open Polish theatrical reflection to the feminist criticism perspective is "Inna Scena" [Different Scene], a project in progress since 2005 in the Theatre Institute in Warsaw. Its goal is also to propose a re-reading of the history of Polish theatre and dramatic canon in this spirit. The result of the long-term project is an array of collective critical volumes-none of the texts they contain, however, concern the counter-culture theatre.

The only Polish text which touches on this subject is the article Pteć performera [Performer's gender] written by Agata Adamiecka-Sitek and Weronika Szczawińska ("Didaskalia" no. 100, 2010). The authors analyse the works of Jerzy Grotowski, the greatest rebel and theatrical experimentalist of those times, and see his discourse on the universality of the body and experience as merely a camouflage covering the reproduction of cultural patterns. According to my diagnosis, the paradox of Grotowski's artistic work, brought to light by the authors, may, in a broader perspective, apply to the whole territory of counter-culture theatre, and the question about women's place in Grotowski's anthropological project is also a question about their status and position in ensembles which directly or indirectly drew from his works.

\subsection{Ewa Benesz, the Great Absent in the Polish Theatre}

Therefore, the subject of this text is Ewa Benesz who was frequently practicing with Jerzy Grotowski (note 3), considered one of the most influential theatre practitioners of the $20^{\text {th }}$ century, but was unable to find her own space in his anthropological project. Understanding the great potential of Grotowski's works, she began her own artistic project, where she develops his approach, yet she does not continue his path directly.

In the 1970s and 80s, in an act of a countercultural rebellion, she would wander through Polish villages with a huge knapsack and a pocket edition of Pan Tadeusz, reciting the national epic written by Adam Mickiewicz; at the beginning of the 1970s, together with her friends, she founded her own Theatrical Studio in Puławy which was soon closed down due to political reasons. Following the Puławy theatre's closedown, together with a painter, Mira Żelechower-Aleksiun, she engaged into a unique, artistic and theatrical enterprise; the exceptional in its kind, multi-format, street performance lasting the entire day, based on The Duino Elegies by Rainer Maria Rilke. Between 1977 and 1981, they presented it multiple times in various cities of the country. Her urban ventures with Rilke and village expeditions with Mickiewicz came to an end in September 1981. As a matter of fact, with the martial law being introduced in Poland, she could not find a space for her artistic activities in Poland and, accompanied by Rena Mirecka, a long time Grotowski's actress, she had left the country. In subsequent years, while travelling all over the world, they had implemented three extensive paratheatrical projects.

During her journeys, she got acquainted with various theatrical practices of different cultural traditions which she embedded into her own artistic activities. While travelling to the Far East, she learned the basic meditation practices and the elements of the hatha yoga, which she would be practising until today. On her trip to Latin America, she had an encounter with shamanism, learning the steps of the shaman dance which is still performed during her workshops. In 1992, together with Rena, she found a house in Sardinia. The house located in the very heart of wild mountains, spreading north-east of Cagliari, with simple, white, plastered walls, was baptised Casa Blanca. Situated far from civilisation, the house became an ideal place not only to have a rest after a long journey but above all, to create one's own house of creative work. Several years later, when their creative roads split, Ewa decided to stay in Casa Blanca. Since that time, she has conducted three times a year her original paratheatrical workshops for the participants from all over the world. Bearing the name In the Act of Creating, they topically focused on the Mediterranean cosmogonic myths, and at present, concentrate on a broadly understood anthropology of theatre. Ewa dubs them the Experience.

\section{2. "The Crystallized Secretions of Once Living Human Experience": Methodology and Techniques}

The project has an interdisciplinary character for at least two reasons. Firstly, due to the subject of the proposed project which combines theatre studies problems with sensitivity to the role of women in culture, projecting these questions on a wider social canvas, including especially the important category of experience. Secondly, due to the rich, varied methodology which will include deepened biographical inquiry with Ewa Benesz, analysing and interpreting theatre performances and historical - including archival - research on the development of the counter-culture movement in Polish theatre.

It is worth stressing that I had the unique opportunity to watch the actress at work and took part in workshop she organises in her hermitage in the Sardinian mountains that are called In the Act of Creating. The residential experience started on Saturday 22nd, and lasted until Friday noon, 28th of August. Thanks to practical participation in theatrical actions undertaken by my ethnography's protagonist, I have gained a special kind of imagination and sensitivity needed to analyse 
her interpretations of her own experiences.

\subsection{The Anthropology of Experience as the Methodology}

The most important research category in the presented project is the category of experience. I take on the topic of experience being fully aware of insurmountable difficulties that it poses, the most fundamental one being its dubious cognitive availability. By that very fact, my research fits into the kind of "experiential turn" (Bachman-Medic 2016) which can be observed in contemporary humanistic reflection. Scholars' interest in experience resulted in scientific papers dedicated to this category. First of all, I should mention Dorota Wolska's work Odzyskać doświadczenie. Sporny temat humanistyki wspótczesnej [Reclaiming the experience. The controversial topic of contemporary human sciences] (2012) where experience appears mostly in the existential approach as a category of humanistic reflection and a matter of dispute within its frame. Another important work is Martin Jay's history of modern thought on experience Songs of Experience. Modern American and European Variations on a Universal Theme (2006). The most important work for the methodology of this project is, however, the collective volume edited by Victor W. Turner and Edward M. Bruner The Anthropology of Experience (1986); a work which understands experience as the central category of human life and actions and, thanks to Turner's reflections, anticipates the possibility of shifting the orientation of anthropology itself (Godlewski 2009).

Turner's meditations were directly inspired by the works of a German philosopher Wilhelm Dilthey [1833-1911] and his concept of Erlebnis and his understanding of experience as something that has been "lived through". I assume that experience is incomplete until "the lived-through" is attributed with meaning during a creative retrospection when events and impressions are given "meaning" - even if meaning equals "lack of meaning" (Turner, 1982, p. 7-20). Thus, in these corresponding reflections experience fulfils itself not really in the act of understanding, but in the creative act consisting in trying to articulate it.

By adopting such research perspective, I understand all creative acts of the women I study as structured units of experience, as experiences they put in the structural framework, as interpretations and representations of their own experiences. Therefore, the object of my research will be all kinds of "the crystallized secretions of once living human experience" (Turner, 1982, p. 17), various interpretations of expressions of life (Dilthey 1976), not only in the form of the narratives of women associated with counter-culture, but also the performances they create, the monodramas and workshops. Thus, I will interpret women who interpret themselves both through telling their stories and through dancing them out or performing them on stage.

While taking on studying experience, I am aware that it is not possible to reach experience directly, but only mediated by interpretation which, in turn, is always socially based (Hastrup 2008). This project is thus constructivist in its nature, which means it assumes that "reality" is merely a social construct, created in the process of its continual interpretation and reinterpretation, and any attempt to describe it is nothing but an illusion (Kuper 1988). From this perspective, experience - fulfilling itself through the act of interpretation - transforms reality and reveals the processual way of culture's existence. Therefore, by trying to articulate their experience, the actresses I study put their experiences into circulation (Turner 1986, p. 37) and by this very fact, they re-experience and remake an important fragment of the history of the Polish theatre that is the counter-culture theatre.

From this perspective, the category of experience, understood as a process which is not only shaped by culture, but also shapes and re-shapes both the individual and - through its articulation, i.e. objectivisation of its meaning - culture, may prove to be extremely useful in the area of theatre studies, anthropology, cultural studies and women's studies.

\subsection{Autoethnography as a Type of Academic Writing}

The aim of this paper is not only to empower actresses creating counter-culture theatre in Poland through recounting their experiences and analysing their various interpretations of expressions of life; this work also emphasizes my voice and my active intervention in the discourse of the history of Polish theatre. Therefore, I reckon my research should be included under the rubric of autoethnographic research and writing (e.g., Ellis \& Bochner, 2000; Reed-Danahay, 1997). "I am both the subject and the researcher of this particular investigation." - I must agree with with Majatta Saarnivaara's statement that in this case - "Within the text I move between my personal and academic identities, narrating autobiographical episodes from my life. My personal voice describes where I was and what happened. However, the focus of the story is elsewhere. The events of my life serve only as a framework and materials for reflecting on the phenomenon of transgression. As a researcher, I analyse, interpret, and use the episodes to construct a new narrative whose purpose is to communicate a certain insight and meaning associated with transgressive experience" (Saarnivaara, 2003, p. 590).

I see autoethnography more as a writing strategy, although autoethnographic theorists conclude that this could be "both a method and a text" (Reed-Danahay, 1997, p. 9), which display "multiple layers of consciousness, connecting the personal to the cultural" (Ellis, Bochner, 2000, p. 733). I agree with the definition of two female researchers - Laura Ellingson i Carolyn Ellis - who claim that "autoethnography is a broad and ambiguous category that encompasses a wide array of 
practices" (Ellingson, Ellis, 2008, pp. 449-450). It is them who noticed that within autobiographical genre of writing and research there are various research tendencies, each with different level of emphasis placed on the very act of writing and a research process (graphy), a culture which is being researched (ethno) and a researcher (auto). This is the reason why they distinguish two separated kinds of authoethnography - evocative and analytic, pointed out the fundamental difference: "Analytic autoethnographers focus on developing theoretical explanations of broader social phenomena, whereas evocative autoethnographers focus on narrative presentations that open up conversations and evoke emotional responses" (2008, p. 445).

The methodology that I am using is closer to the evocative autoethnography, which emphasizes rhetoric and stylistics of the ethnographic statement which leads to greater focus on creating a palpable emotional experience as it connects to, and separates from, other ways of knowing, being, and acting in/on the world" (Holman Jones, 2005, p. 767) and therefore provokes change. Unlike analytical ethnography, evocative ethnography does not focus on analysing researcher's experiences but aims at the paradigm shift in the qualitative research by appreciating politicalness of social research as a great challenge which at the same time justifies itself. Personal, evocative stories seem to be the best method to shape sensitivity and change social consciousness (Holman Jones 2005; Denzin 1997). Ruth Behar describes this writing strategy as ,anthropology that breaks your heart” (1996).

The idea of ,anthropology that breaks your heart” apart from focusing on the most intimate and hidden and at the same time readily available realms to the researcher, includes also a kind of interactive and communication challenge. By writing about ,anthropology that breaks your heart" and "doing" it, Ruth Behar tries to encourage researchers to equally sensitive response to the paper, to "cultivate" anthropology which is really meaningful for them. Behar's intention is to convince scholars to tackle genuinely important problems that happen here and now, to speak on social, anthropological and philosophical issues, to reveal the world of emotions, to concentrate on the researcher's experiences without fearing accusation of subjectivity and exhibitionism. This is the kind of challenge I intend to meet.

\section{3. "In the Act of Creating": to be a Participant of the Ewa's Experience}

These who decide to participate in the Experience, work from dawn to dusk, spending all days together in separation from the reality which constitutes their everyday existence. It is the work formula borrowed from Grotowski, both in the times of Parateatr, and Theatre of Sources. The way the paratheatrical Special Project (Note 4), began was described by Leszek Kolankiewicz: “...on the first few days we perform some household duties. We abstain from talking about what is going to happen here. The habits brought from the city, like the state of protective alert which is indispensable there, the dullness of senses or indifference are slowly dying down in us. We gradually plunge into the rhythm of a different life. [...] We slowly become sensitive to one another, we feel our continuous, tangible, warm presence. We begin to form one, movable, multi-person body. [...] It seems as if our collective body touches the ground more strongly, more tightly due to the fact that it collectively immerses into it. We learn to inhabit it.” (1978, pp. 25-26).

This picturesque account could serve equally well as the description of the first days in Casa Blanca. Like Ryszard Cieślak's trainees, Ewa's graduates tear off contact with their everyday activities for a few days of mutual work in order to "take off burdens accumulated in our heads and on our shoulders, to relax, to discard all which plagues us, that is like a worn-out clothes, and transfer it into an act of creation, an act of transformation (Benesz 2013), and all this away from a rush of big cities and out of the reach of the seemingly omnipotent Internet, without electric power and warm water, in silence and loneliness. To achieve thus formulated purpose within several days long separation, Ewa demands from the arrivals both obeying the rules applicable in Casa Blanca and discipline in performing a strictly specified day's agenda which begins at dawn with the Road to the Sun, and ends when the sun goes down behind the line of the horizon.

"Motionless on a forest clearing, we say goodbye to the setting sun, and, forming a circle, we greet it murmuring in the morning" (Kolankiewicz, 1978, p. 29), reported the participants of Grotowski's paratheatrical activities. During the Experience in Casa Blanca, this particular adoration takes place in front of an old tree with a thick trunk inviting to climb it, which is growing in front of the house. Ewa dubs the tree in Italian carrubai. She sweeps the dry leaves and hard pods of a chocolate colour away from the shaded square with a broom to prepare the ground for the Action which takes place every evening. The carrubai will be its participant together with other participants. For as Grotowski wrote, a tree is a powerful entity with a very strong personality and strong field of activity. "When somebody closes one's eyes and passes by the tree he will feel when he passes by it." (2012, p. 628). We do not perceive the presence of trees because of our internal turmoil which deafens the perception. "It is sufficient to become silent", Grotowski writes as if silencing one's thoughts would be an activity demanding no effort. Stopping every noise, however, not only verbal but also the "talk of movements" (Grotowski, 2012, p. 971), which is a necessity of a continuous expression, mimic reaction and the expression of gestures is a difficult task the fulfilment of which Ewa demands from her trainees. During the first days of the Experience, maintaining the external silence which is meant to lead to the internal silence seems to be an arduous undertaking. In due course, when "the habits brought from the city died down", it becomes an appropriate, obvious, 
apparent and somehow natural behaviour.

Apart from a close contact with nature and everyday wandering through the mountains at dawn which helps the trainees to easier synchronise their rhythm of day and night with the rhythm determined by the wandering of the Sun in the sky, the obligatory point of the day is the yoga session following dinner according to the Iyengar's method which is conducted by Ewa and which lasts for several hours.

The conscious work with breathing, with one's own body, overcoming the resistance of muscles and controlling the mind help to enter the state which is close to meditation. The fitness of the 70-years-old Ewa's body, although paradoxically obvious due to her everyday practice cultivated already for several dozen years, is astounding. The stretched, flexible muscles let her stay for a long time in the most demanding positions, perfectly assimilated by her states of mind which some of her trainees can hardly perform on the basic level. When the time comes for the savasana, the position of relaxation which ends the session and which lasts for half an hour, the tired bodies do not dream about anything else.

Savasana which signifies "the position of the dead" is a form of a concentrated meditation, the practice of withdrawing senses (pratyahara), while remaining careful and present at the same time. The achievement of this particular kind of awareness was also recommended by Grotowski and Ewa refers to it indirectly in her later activities. "Awareness means consciousness which is not connected with speech (a machine to think) but with the Presence.” (Grotowski 2012, p. 844). It is the principal task of the Experience. Ewa calls it "a pure and undisturbed relation with You [which - K.K.] requires a pure perception." [...] "It is a laborious activity until it becomes a grace", she writes and underlines that the most problematic in the achievement of this state is curbing the mind which "defends itself with all its might not to lose its function of judgment, since - like it or not - it gives judgments all the time" (Benesz 2013). Remaining for half an hour in the state of symbolic death releases the mind as if entering the crack of infinity helped to set up priorities anew, to discard the ties with everything that disperses senses, and finally, to get rid of everything that blocks the contact with oneself.

"It is strange to see that all that was once motionless is now floating so loosely in space", Ewa was saying reciting The Duino Elegies some years ago. "And it's hard being dead, [...], before one gradually feels a little eternity" (Rilke, 2001, p. 11). She can recall the words from The First Elegy even today, carefully putting blankets around the bodies of her symbolically dead trainees immersed in savasana.

\section{The One Who Knows: the First of Ewa's Figuration}

On the psycho-physical level, Ewa's Experience is for me a searching for what a man can do with his loneliness among other people, and in what way silence and loneliness can be transferred into a creative act - first, individual and then, being an effect of the activities of the entire community formed for these few days. Offering the participants of the Experience the evening meetings which are the culmination of the day preceded by the all-day long state of calmness, Ewa offered us not only a possibility of working on our own egos but, primarily, a possibility of a true, inter-human Meeting. How is it possible, however, to enter the interaction with a stranger whom, during the day, you are united with, in a common, silent activity?

"At the beginning", Ewa says, "there are no specified tasks, specified roles. We begin at the point zero: here we are in an empty space. [...] I place roses, a basin with water and a stone in the middle and I begin to wash the stone. One of the participants begins to cooperate with me, then another one. We put our hands in the water. I start to sing the initial verses of The Enuma Elish [a Babylonian poem about the creation of the world - K. K.], and then, the initial verses of other cosmogonic myths of the oldest civilizations. Alfred picks up a flute..."

Soon, other instruments will join the nostalgic sounds of the flute. Barbara picks up an Arabian bendir, a drum from Morocco which she carries everywhere with her in order to get a deep sound out of it. Cenzo was playing three traditional Sardinian pipes called launedda and their melancholic melody was floating up over the mountains. The sentimental tones of the improvisation were accompanied by a rhythmic rumble of an African djembe, a specific rustle of maracas seeds, the creaking sounds of shekere made from an empty calabash and sea-shells, the ebony beats of Cuban clavers, the idyllic sound of the cows' rings or of an Indian güro reminding us of the frogs' croak. The unique character of that composition of sounds, being a common creation of several dozen playing hands and an identified number of breaths blowing the instruments made each of us want not only to become a part of a collective, creative body providing our own contribution to the composition being created $a$ vista, but also to be influenced by these exceptional, unprecedented, unrepeatable rhythms. The feeling of the most precious temporariness helped us to get rid of all limitations for w while and absorb the omnipresent hic et nunc with all our senses. The belief in the significance of what was happening demanded involvement and encouraged to be present. "The Action requires the presence of You and the exclusive relation with You", says Ewa. "Only the exclusive contact with You unites everything in us which has been divided." In this context, the words of The Duino Elegies reverberate like an echo as if Rilke's mysticism, together with childhood which he sanctified and the never ending attempt to reach one's "internal essence" had accompanied Ewa since the time of her wandering around the Polish cities setting up the peculiar continuum of her experience until today. 
The Sardinian Experience, situated at the end of that line of continuity is a kind of Ewa's creative work culmination and crowns her anthropological and artistic peregrinations. In this way, they become a particular study of the topics most important to her which appeared in her earlier activities, a development of the most important threads of the knowledge accumulated for years, a practical penetration of the sources which has inspired her most. "I am looking for sources [...] which are human truths and generate the truth - in myths, in literature, in archaic techniques and practices, in dances and rhythms, in the oldest songs and vocal techniques", she says, "I believe that from generation to generation, the mankind has preserved the most important things but at the same time, the most practical ones, both when it comes to singing and baking bread" (Benesz, 2013). In her activities, she refers not only to the melody and rhythms originating from various cultures but also to traditional, everyday practices guaranteeing the generations durability, such as baking bread, producing wine or pressing olive.

In the millennium year, and dealing with "the things embedded in the origins of our culture", she begins practical anthropological studies of the Mediterranean cosmogonic myths, and she will be engaged in this work for ten years. However, the work on the myths of creation focuses her attention on plants as if the continuum of her experience has completed a circle. "In every myth of creation, there is a plant", she remarks. "The human being is not alone in every myth of creation. The man is not alone", she repeats remaining deep in thoughts. Nowadays, she concentrates the workshops she conducts around processing three plants she thinks sacred; in spring, she concentrates on ears of grain, in late summer, she works with vine, and in winter, with Pistacia lentiscus from which both Sardinians in the times of starvation and the ancient Egyptians were extracting oil. "In this way, I transfer my knowledge", she says and adds, "I am an old woman and what does an old human being do? - passes over the things to the young ones since the beginning of the world".

Ewa Benesz acts like the One Who Knows, an archetypical woman "as old as time" who is a guardian of the mystery of a cyclical nature of life. It is her, the One Who Knows, La Que Sabe according to the South American mythology, who personifies the remote past and who preserves the female tradition like a chronicler of the female practices. That is how Clarissa Pinkola Estés who studies the archetypes of the Wild Woman describes her: "This old woman stands between the worlds of rationality and myths. [...] [In this place - K.K.] we all realize it once we experience it, but its nuances slip away and change when one tries to pin them down, except when we use poetry, music, dance, and story" (1992, p. 25-26).

Ewa Benesz is the One Who Knows, who "possesses a direct knowledge of seedlings, rootstock, the corn seeds of the world" (Estés, 1992, p. 28). She opens the doors to it by traditional media - songs, dance, stories and rituals sanctified with everyday practices. „The force personified by La Loba records the personal past and the ancient past for she has survived generation after generation, and is old beyond time" (Estés, 1992, p. 25). It's her, who "sings the creation hymns over the bones". And it's her, who "is the road between the living and the dead" (Estés, 1992, p. 29).

\section{La Loba: the Second of Ewa's Figuration}

The sun goes down in the West although it is still hot like at midday. The touch of cool earth, all days long hidden in a shadow provided by the dense crown of the tree brings relief to hot, bare feet which step rhythmically swinging the trainees' bodies forming a circle and bound with arms. The trance-like swinging is accompanied by singing and in fact by a mantra-like intonation of one verse recited by many voices which - when repeated for a subsequent time - becomes more familiar. Its sound becomes more familiar and its meaning which seemed to be forgotten for years becomes a revelation again.

"I turn to the oldest vocal techniques which exist in the world - to Tibet, tantra, Buddhism; I turn to the oldest singing techniques, to shamans, Bonn, Wed, ancient Greeks, to the Gregorian chants. These are the oldest techniques preserved in history", says Ewa who, this evening will play again a role of a midwife monitoring the progress of the Action which is about to happen. Swinging together with other participants, she intones a new song which - when repeated again - is quickly undertaken by the singing collective body. The participants forming a circle, although repeat the song's words without a hesitation, and like Ewa tasting each of its sounds apart, with each successive repetition, begin to carefully study its sounds. "Am I singing? Or is somebody inside me singing and I am only a witness who controls the process?", asks Ewa and a connotation with the Grotowski's text becomes obvious: "For who is the person singing a song? Is it you? But if it is a song of your grandmother, is it still you? But if, through the impulses of your body you discover your grandmother in you, then it is neither 'you' nor 'your grandmother' who was singing. It is you who explores your grandmother who is singing. Or perhaps you go back in time even further, to the time which is hard to imagine; the time when the song was sung by somebody for the first time." (2012, p. 809).

Moving back in time "even further to a place, to a time which are hard to imagine" which Grotowski refers to, evokes a connotation with the leading motif of The Duino Elegies, omnipresent in Ewa's creative work. The students of her working techniques, like the lyrical subject of the Elegies who "went down into more ancient blood streams, into ravines/where horrors lay, still gorged on his forefathers" (Rilke, 2001, p. 21), try to discover a song in themselves which will lead each of them to his/her roots. And when they reach the place it turns out that this experience brings peace and 
consolation, "and every Terror knew him, winked, like an informant" and "Dread smiled" (Rilke, 2001, p. 21). Holding Ewa's hand, every participant enters his own dark spheres in a way, "his inward world, his inner wilderness" [...], where Horror lay, still gorged on his forefathers" (Rilke, 2001, p. 21) and learns how to extract an indestructible life power which is also symbolised by bones in the myth of the South American La Que Sabe also dubbed La Loba.

The only activity carried out by La Loba is collecting wolves' bones. In searching for bones, the Woman-Wolf wanders around roadless tracts, scanning the mountains and the dried river beds. When La Loba constructs the entire skeleton out of the bones she finds, she places herself above her criatura, raises her tired arms and begins to sing quietly. Then, as the legend goes, the wolf's ribs begin to be covered with flesh and fur, and with La Loba's voice echoing through the valleys and her song filling the mountain wilderness, the animal is expanding and the shaggy wolf's tail goes up. "It is a resurrection story" writes Estés (1992, p. 24); the story which gives hope that once somebody finds his own song and sings it, that he can recall something that has been forgotten; he can renew something that needs a renewal, and at the same time, to turn silence and loneliness in himself into a creative act.

\section{6. "You Are Somebody's Daughter": The Residue of Ewa's Experience}

"The noontime was mild; big, high oleander bushes rose along the running water, motionless in the warm air" (Deledda, 1995, p. 61). (Note 6). The spring flowing here and there out of the granite rocks not only writhed, cutting like a stiletto through a solid ground but also floated further in some sections, filling the rocky cracks with green, icy-cold water, thus forming sometimes very deep ponds located on different heights, "surrounded and divided by rocks breaking the course of the murmuring water" (Delleda, 1995, p. 67). Immersing feet tired after the wandering around the mountains in the soothing depths, we regain strength after the laborious journey. Some find enough courage to plunge into the water jumping from a rocky shelf hanging over the water body and let the entire body immerse into the refreshing depth; some, standing on the bank only put their bandanas into the water to put them then on their heated foreheads. Somebody intones a song which other people are not familiar with but which everybody learns quickly and soon its idyllic, multi-voice sounds are drifting over the eucalyptus forest.

In such an idyllic atmosphere, Ewa who is sitting on the edge of the largest boulder spreads a piece of white linen on it, and two participants of the Experience empty out a huge number of bunches of grapes glittering in the sun. Ewa takes a juice-filled bunch of the vine plant and begins to carefully tear off a grape by grape from the branch to then delicately place them in one of the huge bowls prepared for the picked up fruits. We follow her example so that after a few moments, the bowls are full of dark violet grapes and the white linen is stained with burgundy juice. As self-declared wine producers we set in motion all our senses not to miss even the smallest grape. We raise the bunches of grapes towards the sun observing how its rays penetrate the pulp hidden under the skin. We are turning around the picked up grapes in our palms to appreciate their curvy shape and the velvet texture of the skin, and then let them roll from the inside of our palms into the bowl. Tasting from time to time the ripe fruits, we let our teeth cut impetuously through the thin skin and the sweet juice explodes in our mouths.

Although this particular meeting with small pieces of existence is based on devoting our time and the exclusive attention to them, it is paradoxically connected with the existence of each of us. As if we were changing the direction we are looking at and moreover, as if the hardship of the concentration were paying us back. "It looks like the gratitude of things", Jolanta Brach-Czaina is commenting while meditating over a cherry. "When we try to understand the message coming to us from an existential concrete, we ultimately come to understand ourselves" (Brach-Czaina, 2006, p. 15). It is also an intuition shared by Ewa Benesz. In her considerations, the small piece of being which she pays attention to - both a plant, an animal, a natural phenomenon, or another man is concealed under the pronoun You written with a capital letter. "The "I" is revealed only from an exclusive reciprocity with "You", says Ewa provoking meeting with the exclusive You and then helping her trainees to turn it into a creative act. "We return to it and we transfer and resurrect it" (Benesz, 2013), she writes revealing the essence of the Experience with these few words.

The vine on which the August workshops concentrate - one of the three seasonal activities connected with the sacred plants - is not exclusively a pretext to work with mindfulness. For it is not only about the deepening of the contemplation of a grape carried out internally but it is, above all, performing the traditional tasks connected with the pressing of wine which, according to Ewa, as the activity ensuring the survival of the human species for ages, is the procedure sacral in a particular way.

"I think that important human experiences do not die since they are practical", says Ewa. Referring to the rituals deeply set in the European culture, and to the practices important for people brought up near vineyards and particularly well remembered from their childhood, helps to return to one's roots, even for a while, and perhaps even to move "through one's own roots" (Rilke, 2001, 21) towards one's own "forefathers" which inevitably leads to the discovery that "I am from somewhere".

"There is a French saying tu es le fils de quelqu'un [you are somebody's son]. You are not a vagabond, you are from 
somewhere, from a certain country, from a certain landscape [...]. It is you - two hundred, three hundred, four hundred or a thousand years ago, but it is you", Grotowski wrote referring to traditional, anonymous songs which are also being sung during Ewa's Experiences. "For the one who began to sing the initial words was somebody's son, was from somewhere, was from a certain place", Grotowski continues, "so if you find this, you are somebody's son. And if you do not find this, you are not somebody's son, you are separated, impotent, non-creative" (2012, p. 810). Ewa Benesz as a woman "as old as time" - La Loba personifies the power of the old tradition which is handed down from generation to generation. However, it is the tradition handed down particularly by women.

The La Loba myth is not only a "story of resurrection" but also "the story of the underground links with the Wild Woman". The Woman-Wolf "preserves female tradition" and "she is an archivist of feminine intention" (Estés, 1992, p. 25). Tu es la fille de quelqu'un, "you are somebody's daughter", whispers Ewa-La Loba, tipping the juicy grapes from one bowl to another to completely fill them in as women used to do for generations. A huge, round tub is filled with ripe grapes breaking intrinsically from the excess of juice up to its brink. There are two wash basins filled with water which reflects the dark green leaves of the carob tree hanging above it.

Assembled in a circle around the yesterday's harvest, we are rhythmically swinging and singing the traditional Sardinian wedding song which we have just learned. "Rosittedda, Rosittedda ' $n$ tundu, " $n$ tundu", the echo carries the song into the depths of an olive garden surrounding Casa Blanca. And it means "Rositteda, Rositteda, around and around" and reminds me so much of Zosia from "The Wedding" by Wyspiański (Note 7), chanting "Around and around". However, the slow, idyllic swinging has nothing to do with the recalled lethargic and apathy-filled dance of Wyspianski's Mulch. On the contrary, it is an anxious waiting full of readiness, a kind of a prelude to one of the last-but-one Actions which will happen that summer in that temporary community, meant to function for a few days. For in a moment, one of the youngest participants of the Experience, letting two other participants wash her feet from dust and then dry them with cloth specially prepared for the occasion, will hesitantly step down into the tub trampling down the first portion of grapes which happen to fall under her feet. Then, she proceeds delicately, moving the weight of her body on the foot extended forward, to crush subsequent grapes. The juice spurts to the sides, and the girl is radiant with joy. She spreads her arms, raises her head towards the sky and begins to swirl in the crushed grapes, smiling aloud. When her head begins to spin, she slows down the tempo of her movements until she completely calms down her body. She concentrates her attention again on the juicy fruits; she feels like the fleshy balls explode relieving the wine pulp, and the seeds slip through the fingers of her feet. Paying her "undivided attention to the exclusive You", the girl begins to share shyly with the assembled people the earliest memories from her childhood. It is a surprise to everyone that these are memories of the family custom of pressing wine in her uncle's vineyard. Within seconds, she becomes again a small girl standing in the middle of the sea of grapes, raising high her dress not to stain any of the laces with the dark red juice.

"Around and around", the swinging collective body will chant again in Sardinian as soon as the girl's story comes to an end. Then the participants of the celebration will help her to get out of the tub, removing - one by one - the remnants of the pulp from her feet so as not to waste any drop of the precious liquid. Then, they lead her to another water-filled basin to wash and dry her feet tired of pressing the grapes. The girl joins the singing circle adding her voice to other voices. In a moment, yet another person will venture the repetition of that peculiar ritual and pressing grapes with her feet will accumulate enough courage to sing the song most important to her, to reveal to the others a fragment of the verse which evokes the most intimate memories in her or to share with us a memory which is important for her.

"The basis of short monologues and dialogues carried out in verse or prose, spoken or chanted, are the events from the life of each of us", says Ewa. "We share the things which are perhaps the most important in the given moment or which have disturbed us since childhood. [...] The drama is woven from a very delicate tissue and depends on many factors; on the individuality of the people who co-create it; on their courage to take a risk; on the trust we feel towards other members of the group, but in fact, it is all about the trust in ourselves" (Benesz, 2013).

Originally, full of reservation and ultimately, full of trust in others, and above all, to ourselves, bound tightly with our arms, we create a compact circle surrounding the tub full of foamy, dark red nectar. Bending over it in a friendly union, we not only watch the effect of our work with pride but also observe the reflection of our faces on the surface of the mutually pressed wine. The faces which were so strange to each of us at the beginning of the Experience are now extremely dear. Now, we look at them with warm feelings and with the need to remember them forever in the tiniest details. Looking at one another, we have no doubts that something important has happened between us and that it brought to us peace and united us in the way difficult to describe with words. A few-days stay in the Sardinian desolate land has been for all of us without exception a very strong emotional experience, the process both psychologically and physically tiring although ultimately full of refreshing and healing power bringing peace and consolation.

Each of us, excluded from our own everyday existence and set in a different existence, the rhythm of which is determined by the wandering of the sun in the sky, experienced a moment of a breakdown. It might have been in the shadow of 
carrubo, during a dance in the grape-filled tub or during immersing our heated bodies into the waters of the mountain pond or at any other moment of the mutual work, each time, however, at an unexpected moment, which could have not been anticipated. This feeling of internal crash although initially might seem traumatic was in effect extremely relieving. The presence of Ewa, The One Who Knows guaranteed us, living through a process of a personal renewal, the feeling of safety. Surrounding us with a loving care, she helped us "to get rid of the burdens accumulated in our heads and on our shoulders, to relax, to get rid of everything which plagued us [...] and to transform it into the act of creation, the act of transformation" (Benesz, 2013). Utilising her wisdom, she created the conditions for a meeting with another human being and, as Grotowski wanted, for the "complete disarmament in the contact" (Grotowski, 2012, p. 1040) which, in the case of Ewa's Experience, is achieved by mutual dancing, singing or pronouncing everything which for each of us individually "may be the most important at the moment, in a given time, in the recent years or with which we have not been able to cope since childhood." "Every Experience is a great risk", Ewa says, revealing what a great responsibility she assumes managing the whole process of the celebration. "It is tearing people off their everyday existence while this everyday existence is my everyday existence", she adds.

\section{Conclusion}

Some time ago, at the beginning of the 1990s, Ewa, together with her neighbour, visited a village located at the foot of the mountain to buy from the villagers whom she knew a home-made wine. When they reached the farm, the fire was already buzzing in the fire-place. An old woman was sitting in front of the fire-place. Nobody paid any attention to her. She was singing. „My mother is singing her life”, said the woman who was selling the wine, noticing the apparent fascination on Ewa's face. When Ewa returned to Casa Blanca she plunged into deep thoughts. "I live on an island where an old woman sits in front of a hearth and sings her own life", she stated. "Why can't I sing my own life?" She made a decision. Like La Loba, she began a journey to search for her bones to compose a skeleton out of them and, raising her arms into the sky, to sing a song over it. And Ewa's bones are the bones of every person, immersed in any culture she had happened to encounter; both in various traditions of the rich Mediterranean culture, and in the culture of the distant India or even of the shaman practices of the Latin America Indians. "For many years, the topic of my work has been singing life", she says today, having spent several years studying the myths of the creation of the world and devoted to practical exploration of the sources of theatre. In this way, she has fulfilled the duty of the Old Woman who "has handed the thing down to the young ones since the beginning of the world", and the duty of the One Who Knows who, in this way, teaches her students the carefulness thus understood. "This is our meditation practice as women, calling back the dead and dismembered aspects of ourselves, calling back the dead and dismembered aspects of life itself" (Estés, 1992, p. 28) - Estés writes, and Ewa adds activity to these words, transferring this which is dead and dismembered into an act of creation. Like La Loba, she is a parallel of many worldly myths in which something that had died is returned to life again and something which has been forgotten is brought back to our memory. The participation in the Experience allows the trainees to make a connection with their own "I", lost or never activated, and to appreciate its value; it helps them to get rooted in their own experience again or for the first time in their lives. And it helps to extract a creation potential from it. The woman "as old as time" shows that discovering one's original source and then the capability of discovering meaning from its inexhaustible resources, the ability to transform its essence and filling in one's everyday activities with that concentrate should constitute not only the set of competences of every human being but also their lifelong duties towards themselves, their ancestors and the entire human population. "Do you not know yet?" (Rilke, 2001, p. 8), Ewa asks each and every of us using the words from her beloved Duino Elegies by Rilke.

\section{References}

Bachman-Medic, D. (2016). Cultural Turns. New Orientations in the Study of Culture. Berlin/Boston: De Gruyter. http://dx.doi.org/10.1515/9783110402988

Behar, R. (1996). The vulnerable observer. Anthropology that breaks your heart. Boston: Beacon Press.

Benesz, E. (2013). Nell'atto del creare. Pratichedaiconfini del parateatro e dell'antropologia del teatro di Ewa Benesz. In M.D’Ambrosio (Ed.) Teatro e parateatro come pratiche educative. Verso una pedagogia dellearti (p. 69-79). Napoli: Liguori Edidtore.

Brach-Czaina, J. (2006). Szczeliny istnienia [Slots of existence]. Cracow: eFKa.

Deledda, G. (1995). Elias Portolu. Martha King (Trans.). Illinois: Northwestern University Press.

Denzin, N. (1997). Interpretive Ethnography. Ethnographic Practices for the 21st Century, London: SAGE Publications. http://dx.doi.org/10.4135/9781452243672

Dilthey, W. (1976). Dilthey: Selected Writings, H. P. Rickman (Ed.). Cambridge: Cambridge University Press.

Ellis, C., \& Bochner, A. (2000). "Autoethnography, Personal Narrative, Reflexivity: Researcher as Subject." In The Handbook of Qualitative Research, Denzin, N. and Lincoln, Y. [Eds.], pp. 733-768. Thousand Oaks: SAGE. 
Estés, C. P. (1992). Women Who Run with the Wolves: Myths and Stories of the Wild Woman Archetype. New York: Ballantine Books.

Godlewski, G. (2009). Victor Turner: ku antropologii doświadczenia, [Victor Turner: Towards the Anthropology of Experience]. Przeglad Kulturoznawczy, 2(6), 165-185.

Grotowski, J. (2012). Teksty zebrane [Collected texts], A. Adamiecka-Sitek, M. Biagini, D. Kosiński, C. Pollastrelli, T. Richards, I. Stokfiszewski (Eds.). Warsaw: Instytut Teatralny im. Zbigniewa Raszewskiego, Instytut im. Jerzego Grotowskiego.

Holman, J. S. (2005). Autoethnography: Making the Personal Political. In Handbook of Qualitative Research, Denzin, N. and Lincoln, Y. [Eds.], 763-791. Thousand Oaks: SAGE.

Janik, K. (2016). Ewa Benesz - życiorys [Ewa Benesz - memoir]. Retrieved from http://teatrnn.pl/leksykon/node/4308/ewa_benesz_życiorys

Jay, M. (2005). Songs of Experience. Modern American and European Variations on a Universal Theme. California: University of California Press.

Kolankiewicz, L. (Ed.) (1978). Na drodze do kultury czynnej: o działalności instytutu Grotowskiego. Teatr Laboratorium w latach 1970-1977 [On the Road to Active Culture, The Activities of Grotowski's Theatre Laboratory Institute in the Years 1970-1977]. Wroclaw: Instytut Aktora - Teatr Laboratorium.

Kuper, A. (1988). The Invention of Primitive Society: Transformations of an Illusion. London: Routledge.

Magnat V. (2014). Grotowski, Women and Contemporary Performance. Meetings with Remarkable Women. New York: Routledge.

Reed-Danahay, D. (1997). "Introduction". In Auto/Ethnography: Rewriting the Self and the Social, Reed-Danahay, D. [Ed]. Oxford and New York: Berg Publishers.

Rilke, R. M. (2001). The Duino Elegies. In The Poetry of Rainer Maria Rilke. A.S. Kline (Trans.). Poetry in Translation.

Roszak, T. (1995). The Making of a Counter Culture: Reflections on the Technocratic Society and Its Youthful Opposition is a work of non-fiction. New York: Anchor Books. Doubledat \& Co.

Saarnivaara, M. (2003). Art as Inquiry: The Autopsy of an [Art] Experience. Qualitative Inquiry, 4, 580-602. http://dx.doi.org/10.1177/1077800403254225

Turner, V. (1982). From Ritual to Theatre. New York: Performing Arts Journal Press.

Turner, V. (1986). Dewey, Dilthey and Drama. An Essay in the Anthropology of Experience. In The Anthropology of Experience, Victor W. Turner and Edward M. Bruner [Eds.], pp. 33-45. Urbana: University of Illinois Press.

Wolska, D. (2012). Odzyskać doświadczenie. Sporny temat humanistyki wspótczesnej [Reclaiming experience. The controversial topic of contemporary human sciences]. Cracow: Universitas.

\section{Notes}

Note 1. Conversation I carried out on 28 August 2015 in Casa Blanca in Sardinia. All subsequent quotations from Ewa Benesz not supplemented with references come from that conversation.

Note 2. Unlike in the Western Europe, where Ewa's methods are very well known and appreciated by artistic schools and even incorporated into larger educational programs, e.g. her project called Source Acting Practices was the part of the training program of the Italian Ministry of Education (2003). Ewa's work is in the area of interest of not only actors and practitioners, but also non-Polish theatre and culture researchers. Virgine Magnat published a book two years ago titled Grotowski, Women and Contemporary Performance. Meetings with Remarkable Women (2014). Ewa Benesz is one of the main characters along with women, who continue to collaborate and carry out legacy of Grotowski in their own creative performance practices.

More information and multimodal resources in Polish on Ewa Benesz on the webpages of Multimedial Library of Brama Grodzka Center - NN theater: http://teatrnn.pl/leksykon/node/4308/ewa_benesz_życiorys

Note 3. Jerzy Grotowski (1933- 1999) was a Polish experimental theater director and theorist whose approaches to acting, training and theatrical production have significantly influenced alternative theatre today.

His artistic work had basically three stages: Theater of the Performances, which lasted until 1970's, undertaken by "13 Row Laboratory Theatre", in which he took over the artistic directorship. The most significant and breakthrough production by Grotowski's theatre was Apocalypsis Cum Figuris, which drew on quotes from the Bible, the works of Fyodor Dostoyevsky, Thomas S. Eliot and Simone Weil. This performance became the most famous of Grotowski's 
productions throughout the world and at the same time was his last theatre production.

In the 1970's Jerzy Grotowski slowly began to abandon theatre and started a new episode of his artistic research called Theatre of Participation. He wanted to find a new form of inter-personal understanding based on bodily and mental sensitivity and communal relating in action. In 1976 Jerzy Grotowski presented a new research program that he referred to as Theatre of the Source, consisted of looking at rituals from various parts of the globe and attempting to find the common denominator between them.

Grotowski has his continuators who run The Work Center of Jerzy Grotowski in Pontedera. More information in English about the Workcenter and its brief history on the webpage: http://www.theworkcenter.org/brief-history/.

More information about Jerzy Grotowski in English on the webpage: http://culture.pl/en/artist/jerzy-grotowski

Note 5. Special Project is a paratheatrical project of Ryszard Cieślak. It is an attempt to implement the idea of The Holiday by Grotowski which had been implemented in a separation by the closed groups of participants between 1973 and 1976 under the direction of the originator. This peculiar creation was based on the principles of an active participation and spontaneous interaction between the participants of the drama.

Note 6. The quotation from Deledda's novel is not occidental - the Italian Nobel Prize laureate knows perfectly well how to reflect in words the beauty of the landscapes of her native island.

Note 7. Wyspiański's drama in allegorical way presents the spirit of the Polish nation. The most symbolic scene is the Mulch's dance in which all the wedding guests are dancing like puppets, that symbolizes servitude, torpidity, listlessness and apathy of the nation (Mulch, the phantom in the form of an animate winter straw usually used to covering for flowers).

\section{Appendix}

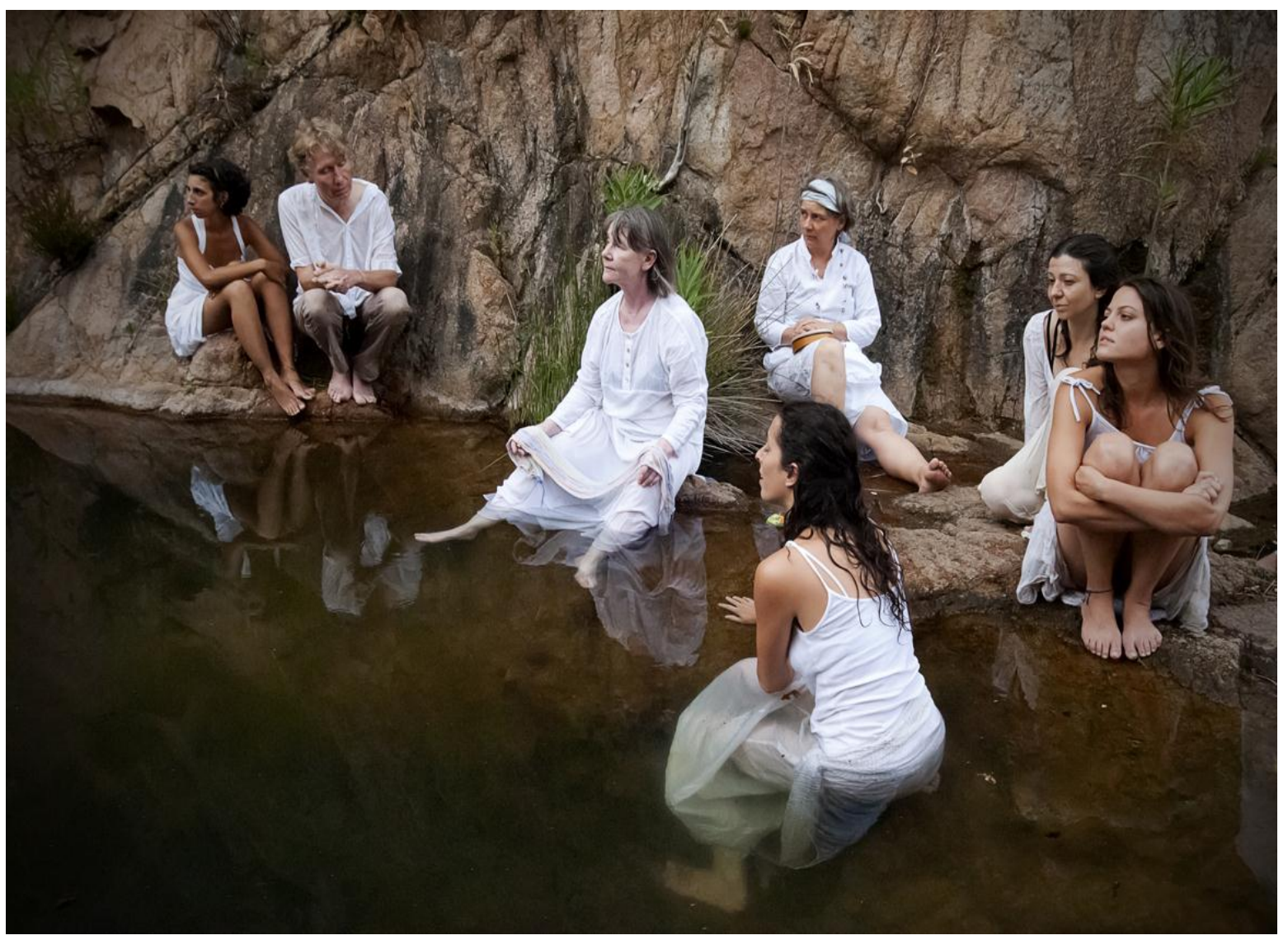

Photo 1 


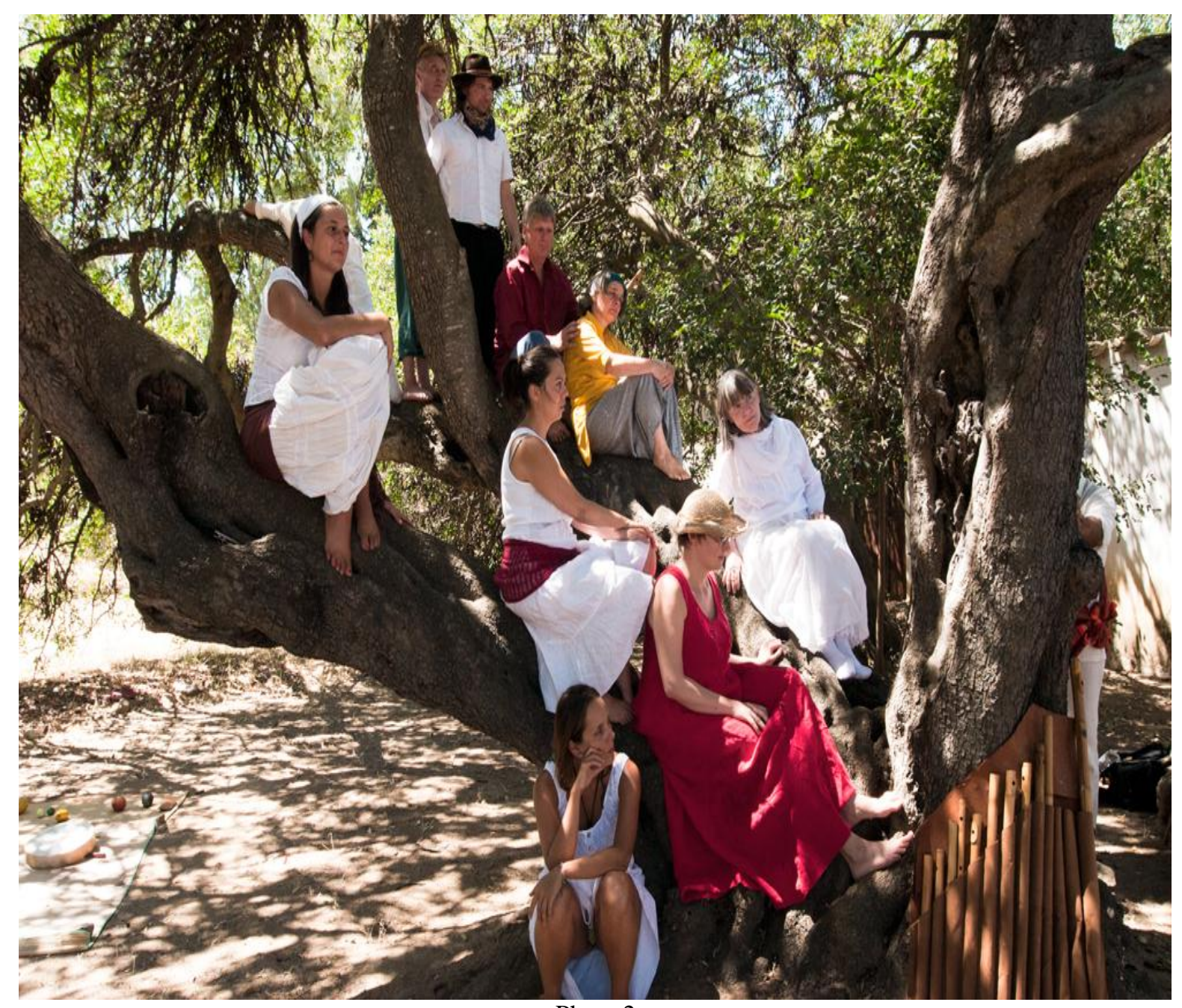

Photo 2 


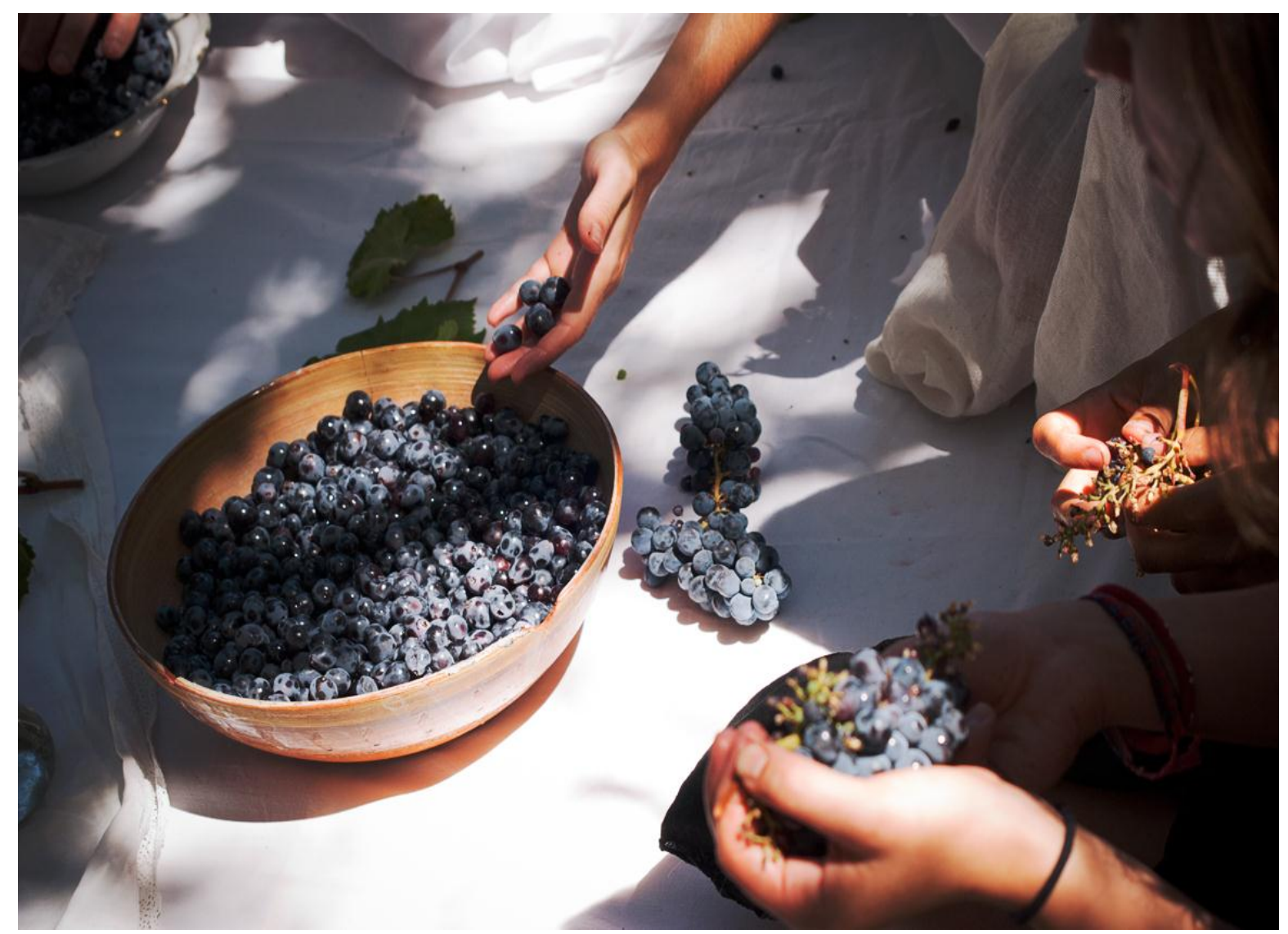

Photo 3

\section{Notes}

1. Ewa Benesz among participants of the Experience sitting at the natural spring. Photo created by Celeste Taliani. Taken on August 23, 2010.

2. Ewa Benesz and participants of the Experience sitting on the carrubai tree. Photo created by Celeste Taliani. Taken on December 14, 2012.

3. Selecting grapes during the Experience. Photo created by Celeste Taliani. Taken on July 22, 2012.

The photos were taken for the documentation of the research project Meetings with Remarkable Women/Tu es la fille de quelqu'un directed by Virginie Magnat and funded by the Social Sciences and Humanities Research Council of Canada and the Grotowski Institute.

\section{Acknowledgements}

This work was supported by National Science Centre, Poland (grant number: 2014/15/N/HS2/03863)

\section{(c)) EY}

This work is licensed under a Creative Commons Attribution 3.0 License. 